\title{
Covid-19 and asset management in EU: a preliminary assessment of performance and investment styles
}

\author{
Syed Kumail Abbas Rizvi ${ }^{1} \cdot$ Nawazish Mirza $^{2}\left({ }^{10} \cdot\right.$ Bushra Naqvi $^{3} \cdot$ Birjees Rahat $^{2}$
}

Revised: 28 May 2020 / Published online: 11 June 2020

() Springer Nature Limited 2020

\begin{abstract}
The likelihood of pandemics has been perceived very low till very recently. Therefore, the exponential spread of Covid-19 was a major surprise that has resulted in a global rout of financial markets. In this study, we document some preliminary evidence of performance and investment styles of European funds during the evolution of Covid-19. We assess the period between January and May 2020 and categorized the spread of contagion in three phases. The results document that Social Entrepreneurship funds demonstrated positive returns across the three phases, while most of the other subcategories plunged into negative zone. Our findings on style analysis suggest that fund managers have been drifting from high risk option to low risk in terms of size and investment strategy. Similarly, there has been a switch from high risk to relatively less sensitive sectors and a transition of investment from countries with higher to those with lower number of cases.
\end{abstract}

Keywords Asset management $\cdot$ Covid-19 $\cdot$ Coronavirus $\cdot$ Style analysis $\cdot$ Risk-adjusted performance

JEL Classification $\mathrm{G} 10 \cdot \mathrm{G} 11 \cdot \mathrm{G} 14$

\section{Introduction}

The viral epidemics have not been considered a significant risk till very recently. This is primarily due to the fact that we have not witnessed any major disease outbreak for quite some time. The focus has been primarily on the volatility that may emanate from climate changes, socioeconomic issues, and other investment risks. There is scant evidence on the economic and social impact of an epidemic. Some

Nawazish Mirza

elahimn@excelia-group.com

Syed Kumail Abbas Rizvi

kumail@lahoreschool.edu.pk

Bushra Naqvi

bushra.naqvi@lums.edu.pk

Birjees Rahat

rahatb@excelia-group.com

Lahore School of Economics, Lahore, Pakistan

2 La Rochelle Business School - Excelia Group, La Rochelle, France

3 Lahore University of Management Sciences, Lahore, Pakistan notable studies include Yamey et al. (2017), Almond (2006), Kelly et al. (2011) that focus on the health costs and social impact of viral infections due to a higher mortality rate. Fogli and Veldkamp (2013) argue that health-related costs are correlated with economic activities and have a significant long-term impact on growth.

This issue was only recently taken seriously by IMF and an attempt has been made to assess the economic impact of an epidemic due to cost overruns and social distancing (Bloom et al. 2018). The Q1 global risk report $(2020)^{1}$ by World Economic Forum listed the spread of a contagious epidemic as number 10 among various risks that may impair the economic system. Oddly, soon after the circulation of the report, the highly improbable risk surfaced as a systemic reality resulting in trembling of global financial system from the spread of Covid-19 (the new Coronavirus).

The Covid-19 outbreak has paralyzed major economies with both demand and supply shocks and many financial markets have experienced a decline of up to $20 \%$ from their one year high. Most financial markets have experienced circuit breaker suspensions and volatility has been at unprecedented levels. The credit markets are also turbulent as borrowers are under lot of pressure due to an increase in

\footnotetext{
${ }^{1}$ Published on 15th Jan 2020.
} 
business risk. Given that total borrowing of corporate and household debt is at a record high across USA and Europe, a deteriorating operating landscape could lead to a very high default rate (Blundell-Wignall 2011; Lannoo et al. 2013; Zabai 2017). Therefore, many central banks are intervening constantly to provide a breathing space for the participants. ${ }^{2}$

The speed at which economic deterioration is taking place is a primary concern and therefore, it constantly pushes regulators and investors for dynamic responses. Given that equity and debt markets are in rout, the investors are using alternate options to park their funds. A usual recourse during periods of high volatility are treasury instruments (Baele et al. 2019), but Covid-19 has put extreme pressure on public finances resulting in declining yields on treasury instruments.

Investments in funds are usually preferred by risk averse investors who, for a price, allow their portfolio to be managed by an agent (the fund manager) (Carhart 1997; Fama and French 2010). The actively managed funds are expected to demonstrate superior performance compared to individual securities or passive indices particularly in declining markets (Chevalier and Ellison 2017; Golec 1996). This implies that the variation in fund returns is likely to reflect the impact of a systemic shock (like Covid-19) compared to other indices or stock returns. Moreover, as these funds vary in their composition and style, analyzing their returns are central in quantifying the impact across different categories and investment styles (Naqvi et al. 2018; Reddy et al. 2017). Therefore, in this paper, we evaluate the impact of Covid19 on different types of actively managed funds in Europe. We adopt two mechanisms for this analysis. Initially, we assess the risk-adjusted returns across different categories to observe the comparative performance during this period of high volatility. Thereafter, we conduct a style analysis to understand the investment behavior of funds managers and if there have been style transitions with the evolution of the Covid-19.

We derive the motivation for this research from few aspects. Firstly, the contagion of Covid-19 is very dynamic across European Union (EU). The policy response and consciousness about the severity were very casual during the first few weeks. However, soon after, the infection spread at an exponential rate which resulted in a shift of epicenter of the pandemic from mainland China to Europe. This mandated the EU to take stern and unprecedented actions in an attempt to curtail the spread and flatten the curve. Most member states closed their frontiers imposing strict

\footnotetext{
${ }^{2}$ Some recent interventions include a cut in the base rate by the Fed and adding liquidity to repo market, Bank of Japan's commitment for an increase in asset purchase plan and the People Bank of China's injection of USD 240 Billion in the financial system.
}

movement restrictions and lockdowns. Therefore, the overall response has been extremely staggered and consequently financial system has witnessed periods of mass speculation preceding an actual state intervention. This makes it interesting and timely to assess how the evolving state of Covid19 impacted the funds' performance and investment styles across EU.

The second inspiration for this research was to gauge the impact of Covid-19 on an eclectic range of funds that are available in Europe. The most noteworthy of these include Social Entrepreneurship funds which were legislated and introduced some eight years ago. These funds mostly invest in social enterprises which concentrate on social missions and are nonprofit. Therefore, it is interesting to observe the resilience of these funds against the outbreak and their comparative performance vis-à-vis other funds. As the financial markets are experiencing extreme volatility, we employ a methodology that is robust for distributions with higher moments. The rest of this paper is organized as follows. Section "Data and methodology" presents our data and methodology, section "Empirical results and discussion" includes results and discussion while section "Conclusion" provides some tentative conclusions.

\section{Data and methodology}

In this study, we assess risk-adjusted performance of EUbased investment funds to understand the returns dynamics during the outburst of Covid-19. Further, we complement this analysis by undertaking the investment style analysis. This is to observe if there have been changes in investment behavior by funds managers in response to the evolving situation. The EU has been badly affected by the outbreak with ten member states reporting approx. $20 \%$ of global infections and $35 \%$ of the total death count. ${ }^{3}$ There are 27 members of the EU but for this study, we limit our selection of funds from the countries that have reported more than ten thousand infections as on the cutoff date. This limits our analysis to 15 countries which are listed in Table 1 along with key infection statistics.

For our analysis, we consider three broad categories of mutual funds. These include capital, money market, and alternative investments funds. Each of these has two or more subcategories depending on the nature of the funds under management. In order to have homogeneity across the sample and sufficient data for analysis, we only include funds that were introduced prior to January 2019 and their net asset value (NAV) is available until May 24, 2020. We

\footnotetext{
3 These statistics are as on May 24, 2020 which is cutoff for this study.
} 
Table 1 Covid-19 statistics for selected EU countries

\begin{tabular}{llllr}
\hline Country & Total cases & Total deaths & $\begin{array}{l}\text { Total } \\
\text { Cases/ } \\
\text { million }\end{array}$ & Death rate $(\%)^{\mathrm{a}}$ \\
\hline World & $5,502,606$ & 346,761 & 706 & 6.30 \\
Spain & 282,852 & 28,752 & 6050 & 10.17 \\
Italy & 229,858 & 32,785 & 3801 & 14.26 \\
France & 182,584 & 28,367 & 2798 & 15.54 \\
Germany & 180,328 & 8371 & 2153 & 4.64 \\
Belgium & 57,092 & 9280 & 4928 & 16.25 \\
Netherlands & 45,236 & 5822 & 2641 & 12.87 \\
Sweden & 33,459 & 3998 & 3315 & 11.95 \\
Switzerland & 30,736 & 1906 & 3554 & 6.20 \\
Portugal & 30,623 & 1316 & 3002 & 4.30 \\
Ireland & 24,639 & 1608 & 4996 & 6.53 \\
Poland & 21,326 & 996 & 563 & 4.67 \\
Romania & 18,070 & 1185 & 939 & 6.56 \\
Austria & 16,503 & 640 & 1833 & 3.88 \\
Denmark & 11,360 & 562 & 1962 & 4.95 \\
Serbia & 11,159 & 238 & 1277 & 2.13 \\
\hline
\end{tabular}

Source: https://www.worldometers.info/

The data are as on May 24th, 2020

${ }^{\text {a }}$ Death rate is calculated as total deaths/total cases

Table 2 Sample of investment funds (category wise)

\begin{tabular}{lll}
\hline Fund type & Subcategory & No of funds \\
\hline Capital market & Equities & 70 \\
\multirow{3}{*}{ Money market } & Debt & 46 \\
& Treasury & 27 \\
Alternative investments & Corporates & 53 \\
& Private equity & 23 \\
& Real estate & 28 \\
& Venture capital & 18 \\
& Social entrepreneurship & 13 \\
Total & Infrastructure & 18 \\
\hline
\end{tabular}

extract the fund-related data from websites of individual funds. Based on this criteria, the sample distribution as per main and subcategories is presented in Table 2 .

\section{Phases of Covid-19}

The instances of an unidentified infectious disease were originally reported in December 2019 in mainland China (Wuhan). The virus was formally disclosed to World Health Organization (WHO) on December 31st. The first case outside China was established on January 8th, and initial casualty was reported on January 11th. Subsequently, it has spread exponentially and now impacts more than 200 countries across the globe. The EU experienced an upsurge from early March and was quickly declared as the new epicenter of this disease. The impact quickly spilled over to financial markets resulting in historic lows on an intraday basis. In order to quantify the stepwise impact, we classify the evolution of this pandemic into three phases. These are marked as Phase 1, 2, and 3. Table 3 highlights each phase and list some important news date wise.

The phase 1 is from January 1st to 30th which marks the initial stage when the disease was mostly contained within China. The phase 2 is from January 31st to March 8th that reflects the global spread of Covid-19. Finally, the stage 3 is from March 9th to May 24th during which there was an exponential increase in the contagion, mostly across Europe. This phase also marks the period when strict lock down was imposed in EU member states starting from Italy on March 9th. These lockdowns lasted on average 6 weeks or more and started easing out from mid-May. The empirical strategy is detailed in the following subsections.

\section{Risk-adjusted performance during Covid-19}

We begin our assessment by analyzing the comparative risk adjustment funds of our sample funds. Pedersen and Rudholm-Alfvin (2003) noted that an appropriate measure for performance measurement should adopt to dynamics of market, industry, asset classes, and investors' preferences. Therefore, amidst high volatility during this period, we use two risk-adjusted measured that are suitable for higher moments. The first one is adjusted Sharpe ratio (ASR) as suggested by Pezier and White (2006). While the conventional Sharpe ratio is sensitive to market movements ( $\mathrm{Scholz}$ 2007), the adjusted specification does not assume normality and adjusts for skewness and kurtosis of returns. The functional form of adjusted Sharpe ratio is represented as follows:

$\mathrm{ASR}_{i}=\mathrm{SR}_{i}\left(1+\frac{s_{k}}{6} \times \mathrm{SR}_{i}-\left(\frac{k_{r}-3}{24}\right)\right) \times \mathrm{SR}_{i}^{2}$

where $\mathrm{SR}_{i}$ is Sharpe ratio for fund $i, s_{k}$ represents skewness, and $k_{r}$ is kurtosis.

The second metric we employ is reward to Value at Risk (VAR) ratio. Assaf (2015), Iglesias, (2015), and Su (2015) reported that VAR-based models are statistically superior in quantifying market risk. Similarly, Deng et al. (2013) highlighted relevance of Value at Risk in portfolio optimization. Finally, Reddy et al. (2017) noted that the risk-adjusted performance methods with VAR are better suited for NAVbased returns. Following Reddy et al. (2017), we estimate VAR using filtered historical simulation. This is to ensure that our estimates are robust for non-normality and time 
Table 3 Phases of evolution of Covid-19

\begin{tabular}{|c|c|}
\hline Date & News information \\
\hline \multicolumn{2}{|l|}{ Phase 1} \\
\hline Dec 31/Jan 1 & Chinese authorities alert WHO about a string of pneumonia-like cases in Wuhan \\
\hline Jan 11 & First Death Reported \\
\hline Jan 13 & Thailand reports its first case \\
\hline Jan 20 & South Korea Reports First Case \\
\hline Jan 21 & US reports first case \\
\hline Jan 24 & China quarantines 12 cities \\
\hline Jan 30 & The WHO declares the coronavirus outbreak as a Public Health Emergency of International Concern \\
\hline \multicolumn{2}{|l|}{ Phase 2} \\
\hline Feb 3 & Chinese stock markets plunge on the first trading day after the Lunar New Year \\
\hline Feb 4 & Belgium confirms its first case \\
\hline Feb 9 & The death toll from the novel coronavirus surpasses the toll from the SARS epidemic of 2002-2003 \\
\hline Feb 13 & $\begin{array}{l}\text { EU health ministers convene in Brussels for an emergency health meeting on how to prevent } \\
\text { COVID-19 from spreading in Europe }\end{array}$ \\
\hline Feb 21 & Italy closes public spaces in ten Italian towns \\
\hline Feb 26 & Germany's minister of health announces the country is "at the beginning of an epidemic" \\
\hline March 8 & France bans gatherings of more than 1,000 people due to coronavirus concerns \\
\hline \multicolumn{2}{|l|}{ Phase 3} \\
\hline March 9 & Italy declares nationwide lockdown \\
\hline March 11 & WHO declares the coronavirus outbreak a pandemic \\
\hline March 12 & France closes all schools \\
\hline March 16 & Spain closes its borders to all non-citizens and residents \\
\hline March 17 & The European Union closes its borders to all non-essential travel \\
\hline March 19 & Italy's coronavirus death toll surpasses China's \\
\hline March 29 & The Netherlands passes 10,000 coronavirus cases \\
\hline April 7 & Paris announces it will ban daytime outdoor exercising \\
\hline April 14 & France extended a nationwide lockdown \\
\hline May 11 & France lifts lockdown \\
\hline May 22 & Globally, authorities reported roughly 5.2 million confirmed cases of COVID-19 \\
\hline
\end{tabular}

varying volatility. Once the VAR is calculated, we use this to compute reward to risk for each fund and then estimate the value weighted mean for each category. The reward to VAR is represented as

$\operatorname{RVAR}_{i}=\frac{R_{i}-R_{f}}{\mathrm{VAR}_{i}}$

with $R_{i}$ and $V A R_{i}$ representing returns and value at risk for each fund (NAV based).

This assessment is done for the complete Covid-19 period till the cutoff date (i.e., from January 1st to May 24th) and is repeated for each of the three phases as outlined in Table 3.

\section{Investment styles during pandemic}

The returns-based style analysis is instrumental to understand the sensitivity of returns to different asset classes, investment strategies, sectors, and geographic concentration.
This deconstruction is construed as a measure of fund manager's investment style. Cao et al. (2017) and Sha (2020) noted that fund managers demonstrate a continuous drift in their styles owing to changing market conditions. The use of style analysis has diverse advantages. It is helpful in recognizing the investment preferences across sectors, countries (Parikh 2019), and investment characteristics (Kaiser 2020). This is useful to compare styles across different funds' types like equity (Herrmann et al. 2016), fixed income (Hou et al. 2019), and alternative investments [(Weng and Trück 2011; Chevalier and Darolles 2019)].

In order to assess investment styles across our sample, we use a standard (Sharpe 1992) factorial approach. The return for each fund is described by the following expression:

$R_{i t}=\left[b_{i, 1} I_{1 t}+b_{i, 2} I_{2 t}+\cdots+b_{i, n} I_{n t}\right]+e_{i, t}$

where $R_{i, t}$ is return of fund $i$ at time $t, I_{c, t}$ is the return on style benchmark for an asset class $c$ at $t, b_{i t}$ is the proportion of the 
funds return explained by the return on asset class $c$ and $e_{i, t}$ is the model residual. The style model suggests that the best explanation of fund's return is captured by the style factor $b_{i, t}$ so that it limits the residual variance $e_{i, t}$. This implies the following:

$\operatorname{Min} \sum_{t=1}^{T} e_{i, t}^{2}=\operatorname{Min} \sum_{t=1}^{T}\left(R_{i, t}-\left(b_{i, 1} I_{1 t}+b_{i, 2} I_{2 t}+\cdots+b_{i, n} I_{n t}\right)\right)^{2}$

with the constraints $\sum_{k=1}^{n} b_{i, k}=1 \quad 0 \leq b_{i, k} \leq 1$ $k=1,2,3, \ldots, n$

In order to assess the investment styles, we use size (large, mid and small), strategies (growth, value, and momentum), and five sectoral and 15 EU countries' specific benchmarks (MSCI) relevant to each fund category. For treasury and real estate funds, we investigate only the country-specific styles. Our focus is to observe the possible drift in style, therefore, we undertake phase-wise analysis and not for the complete period.

\section{Empirical results and discussion}

The results for adjusted Sharpe and reward to VAR ratios are presented in Table 4. In Panel A, we can observe the performance statistics for the complete period (January 1st to May 24th). It is notable that apart from funds specializing in social investing, all other subcategories have negative adjusted Sharpe and reward to VAR ratios. This owes to the fact that the average excess returns during the sample period were negative for other alternative investing, capital and money market funds. The positive performance of social entrepreneurship funds is an exception that remains consistent across each phase of this pandemic. The phase-wise riskadjusted results are given in Panel B, C and D.

During Phase 1, within capital market funds, equities dominated their debt counterparts and also performed better than treasury funds. However, they could not outperform alternative investments. We report statistically significant superior performance for real estate and social entrepreneurship for both performance metrics. The domination of real estate over other categories of capital and money market funds was significant for adjusted Sharpe ratio. However, it remained insignificant for Reward to VAR. During phases 2 and 3, social entrepreneurship funds continued to outperform all other funds for both metrics. Although it must be noted that due to worsening market conditions, the adjusted Sharpe and reward to VAR for social funds kept regressing as we transit from phase 1 to 2 and 3 . The impact is more severe for equity funds which demonstrated positive performance during phase 1 but plunge to a negative zone as we move to phases 2 and 3 .
Table 4 Performance evaluation of funds

Adjusted sharp ratio

Reward to VAR

Panel A: Full period

Capital market

Equities

$-0.14596^{* *}$

$-0.10453^{* *}$

$-0.13405^{* * *}$

Debt

Money market

Treasury

Corporates

$-0.09952 * * *$

$-0.08323 * *$

Alternative investments

Private equity

Real estate

Venture capital

Social Entrepreneurship

Infrastructure

Panel B: Phase 1

Capital market

Equities

Debt

Money market

Treasury

Corporates

Alternative investments

Private equity

Real estate

Venture capital

Social entrepreneurship

Infrastructure

Capital market

Equities

Debt

Money market

Treasury

Corporates

Alternative investments

Private equity

Real estate

Venture capital

Social Entrepreneurship

Infrastructure

Capital market

Equities

Debt

Money market

Treasury

Corporates

$-0.08303 * *$

$-0.06359 * *$

$-0.05828 * *$

$-0.09240 * *$

$-0.08896 * *$

$-0.05127 * * *$

$-0.01758 * *$

$-0.00662$

$0.11826^{* * * *}$

$-0.00778 * *$

$-0.00121$

$0.09579 * * *$

$-0.00306^{* *}$

$0.11106^{* * * *}$

$0.10503 * * *$

$0.02004 * *$

$0.00112 * * *$

$0.00822 * *$

$0.00011 * *$

$-0.01050$

$-0.00514$

$0.05934 * *$

0.01216

$0.12020 * * *$

$0.07577 * * *$

0.01320

0.00017

0.15803 ***

$0.15668 * * *$

0.09459

$0.06782 * *$

$-0.02894 * *$

$-0.01082 * * *$

$-0.01416^{* *}$

$-0.00273^{* *}$

$-0.00332 * *$

$-0.00172 * *$

0.00326

$-0.00191 * *$

$-0.00015 * * *$

$-0.09878^{* *}$

$-0.00631 * *$

$-0.01127$

0.13320 ***

$-0.00670$

$0.08793 * * *$

$-0.02824$

$-0.01607$

$-0.03367 * * *$

$-0.00955^{* * *}$

$-0.01399^{* *}$

$-0.01076^{* *}$

$-0.00433^{* *}$

$-0.00190 * *$

0.00917

0.00714

Alternative investments

Private equity

Real estate

Venture capital

$-0.00168 * *$

$-0.00010 * *$

$-0.08521^{* *}$

$-0.07628 * *$

$-0.01552$

0.05761 ***

$-0.01443$

$0.05289 * * *$

Social entrepreneurship

$-0.03822^{*}$

$-0.01243$

*** Significance at $99 \%$

**Significance at $95 \%$

*Significance at $90 \%$ 
Table 5 Style analysis—phase 1

\begin{tabular}{|c|c|c|c|c|c|c|c|c|}
\hline Capital mar & & Money m & arket & Alterna & e investment & & & \\
\hline Equity (\%) & Debt $(\%)$ & Treasury & Corporate $(\%)$ & $\begin{array}{l}\text { Private } \\
\text { equity } \\
(\%)\end{array}$ & Real estate & $\begin{array}{l}\text { Venture } \\
\text { capital } \\
(\%)\end{array}$ & $\begin{array}{l}\text { Social entre- } \\
\text { preneurship } \\
(\%)\end{array}$ & Infrastructure (\%) \\
\hline
\end{tabular}

Size

Large

Mid

Small

$$
R^{2}
$$

Tracking error

Investment strategies

Growth

Value

Momentum

$R^{2}$

Tracking error

Sector

Manufacturing
Utilities
Mining, construction
and chemicals
Wholesale and retail
Agriculture, forestry
and fishing

Services

$R^{2}$

Tracking error

Country

Spain

Italy

France

Germany

Belgium

Netherlands

Switzerland

Portugal

Sweden

Ireland

Poland

Romania

Austria

Denmark

Serbia

$R^{2}$

Tracking error

\subsection{1}

\subsection{6}

$51.48 \quad$ N/A $\quad 52.15$

$30.57 \quad$ N/A $\quad 22.01$

\subsection{3}

\subsection{5}

17.95

$$
\text { N/A }
$$

25.84

$$
91.76
$$$$
1.43
$$

N/A

78.47

$$
1.71
$$

N/A

0.50

\subsection{7}

20.26

$24.67 \quad$ N/A $\quad 30.77$

$55.55 \quad$ N/A $\quad 48.00$

26.77

19.78

92.01

89.99

N/A

21.23

1.32

1.69

N/A

81.70

\subsection{4}

25.54

$\begin{array}{lll}31.81 & \text { N/A } & 38.70 \\ 21.82 & \text { N/A } & 26.51 \\ 16.85 & \text { N/A } & 9.682\end{array}$

$\begin{array}{lll}15.55 & 18.46 \quad \text { N/A } & 15.52\end{array}$

4.35

2.14

N/A

3.50

10.00

$\begin{array}{lll}8.93 & \text { N/A } \quad 6.08\end{array}$

92.17

93.42

1.33

N/A $\quad 75.86$

N/A

1.32

$\begin{array}{llll}6.12 & 6.06 & 3.15 \% & 5.45 \\ 4.14 & 3.11 & 3.83 \% & 4.24\end{array}$

16.25

$15.37 \quad 22.49 \% \quad 21.03$

$17.32 \quad 24.75 \% \quad 20.75$

$3.63 \quad 2.05 \% \quad 3.72$

$5.53 \quad 3.09 \% \quad 8.59$

$12.21 \quad 12.66 \% \quad 12.31$

$2.50 \quad 1.70 \% \quad 2.02$

$11.58 \quad 7.02 \% \quad 6.25$

$6.14 \quad 3.09 \% \quad 3.24$

$2.05 \quad 1.10 \% \quad 1.38$

$\begin{array}{lll}1.21 & 1.39 \% & 1.14\end{array}$

$5.70 \quad 6.52 \% \quad 4.12$

$5.61 \quad 5.23 \% \quad 4.26$

$1.98 \quad 1.93 \% \quad 1.50$

$90.42 \quad 89.05 \% \quad 89.55$

$\begin{array}{lll}1.94 & 0.20 \% & 0.55\end{array}$

$\begin{array}{rr}1.22 & \mathrm{~N} / \mathrm{A} \\ 45.25 & \mathrm{~N} / \mathrm{A} \\ 53.53 & \mathrm{~N} / \mathrm{A} \\ 84.90 & N / A \\ 1.76 & N / A\end{array}$$$
76.39
$$

$4.52 \quad \mathrm{~N} / \mathrm{A}$

$19.09 \quad$ N/A

$89.06 \quad$ N/A

$0.88 \quad N / A$

$\begin{array}{rlrrr}48.53 & \text { N/A } & 69.76 & 10.31 & 10.57 \\ 10.04 & \text { N/A } & 13.10 & 0.37 & 37.44 \\ 13.28 & \text { N/A } & 0.54 & 1.20 & 28.29\end{array}$

$\begin{array}{rlrrr}18.97 & \text { N/A } & 10.61 & 38.74 & 5.18 \\ 2.09 & \text { N/A } & 0.19 & 1.75 & 16.38\end{array}$

$\begin{array}{rlrrr}7.10 & \text { N/A } & 5.80 & 47.63 & 2.14 \\ 94.76 & \text { N/A } & 95.03 & 97.50 & 84.35 \\ 1.28 & \text { N/A } & 0.48 & 0.17 & 1.14\end{array}$

$\begin{array}{rr}4.12 & 8 \\ 3.10 & 7.19 \\ 15.13 & 10.7\end{array}$

$8.55 \% \quad 3.83$

\subsection{1}

5.21

12.10

13.36

2.17

5.30

3.19

1.03

1.08

2.80

8.47

1.03

92.61

0.41

\section{$7.19 \%$}

$10.73 \%$

$12.13 \%$

$5.97 \%$

$9.78 \%$

$9.64 \%$

$2.45 \%$

$8.43 \%$

$7.69 \%$

$3.70 \%$

$3.28 \%$

$4.85 \%$

$4.60 \%$

$1.01 \%$

$96.60 \%$

$1.01 \%$

2.82

2.94

2.64

3.21

23.85

28.72

1.72

2.59

10.60

1.42

5.88

5.12

1.90

1.16

5.46

4.38

1.35

93.06

1.43

$R^{2}$ represents coefficient of determination and Tracking error captures the deviation between fund and benchmark (in italics)

The treasury funds follow suite with high negative riskadjusted returns in phase 3 .

Our findings, albeit preliminary, are interesting from the viewpoint of social funds. These funds specialize in investing in businesses that have predominantly social missions. Therefore, the returns on these investments are a hybrid of social benefits and financial performance. These initial results suggest that social entrepreneurship funds are 
Table 6 Style analysis-phase 2

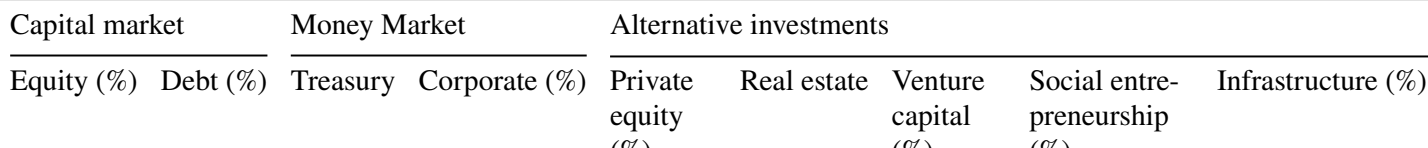

(\%) $\quad(\%) \quad(\%)$

\begin{tabular}{|c|c|c|c|c|c|c|c|c|c|}
\hline \multicolumn{10}{|l|}{ Size } \\
\hline Large & 50.22 & 68.71 & N/A & 67.92 & 5.67 & N/A & 1.95 & 1.83 & 57.60 \\
\hline Mid & 32.89 & 24.83 & N/A & 22.50 & 45.31 & N/A & 50.23 & 3.32 & 35.37 \\
\hline Small & 16.89 & 6.46 & N/A & 9.58 & 49.02 & N/A & 47.82 & 94.85 & 7.03 \\
\hline$R^{2}$ & 94.86 & 91.47 & N/A & 85.21 & 86.42 & N/A & 84.63 & 90.67 & 93.20 \\
\hline Tracking error & 0.76 & 0.60 & N/A & 1.37 & 1.17 & N/A & 0.44 & 0.97 & 1.06 \\
\hline \multicolumn{10}{|l|}{ Investment strategies } \\
\hline Growth & 11.78 & 5.55 & N/A & 9.14 & 40.14 & N/A & 35.12 & 53.65 & 51.25 \\
\hline Value & 68.14 & 65.77 & N/A & 53.45 & 20.16 & N/A & 56.17 & 34.29 & 31.25 \\
\hline Momentum & 20.08 & 28.69 & N/A & 37.41 & 39.71 & N/A & 8.71 & 12.06 & 17.51 \\
\hline$R^{2}$ & 93.52 & 89.03 & N/A & 92.36 & 86.37 & N/A & 94.02 & 87.57 & 89.47 \\
\hline Tracking error & 0.92 & 0.88 & N/A & 1.06 & 1.37 & $N / A$ & 0.81 & 0.29 & 1.79 \\
\hline \multicolumn{10}{|l|}{ Sector } \\
\hline Manufacturing & 17.41 & 18.19 & N/A & 22.14 & 20.15 & N/A & 32.92 & 10.80 & 9.22 \\
\hline Utilities & 31.05 & 24.81 & N/A & 29.76 & 23.54 & N/A & 15.85 & 0.39 & 41.29 \\
\hline $\begin{array}{l}\text { Mining, construction } \\
\text { and chemicals }\end{array}$ & 8.08 & 9.64 & N/A & 5.54 & 12.56 & N/A & 0.31 & 1.26 & 16.18 \\
\hline Wholesale and retail & 32.18 & 40.59 & N/A & 31.38 & 32.72 & N/A & 26.42 & 40.57 & 10.26 \\
\hline $\begin{array}{l}\text { Agriculture, forestry } \\
\text { and fishing }\end{array}$ & 7.46 & 3.46 & N/A & 5.17 & 7.35 & N/A & 18.13 & 1.83 & 20.36 \\
\hline Services & 3.83 & 3.31 & N/A & 6.02 & 3.69 & N/A & 6.37 & 45.16 & 2.70 \\
\hline$R^{2}$ & 89.80 & 90.64 & N/A & 88.27 & 86.41 & N/A & 92.53 & 89.10 & 89.37 \\
\hline Tracking error & 0.71 & 0.93 & $N / A$ & 1.12 & 0.43 & $N / A$ & 0.85 & 1.05 & 1.24 \\
\hline \multicolumn{10}{|l|}{ Country } \\
\hline Spain & 2.52 & 4.94 & $2.57 \%$ & 4.44 & 3.36 & $3.98 \%$ & 3.12 & 3.24 & 2.15 \\
\hline Italy & 3.37 & 2.53 & $3.12 \%$ & 3.45 & 2.53 & $2.45 \%$ & 2.30 & 6.53 & 2.61 \\
\hline France & 9.95 & 7.50 & $9.21 \%$ & 13.19 & 9.59 & $7.16 \%$ & 12.35 & 23.11 & 15.48 \\
\hline Germany & 15.60 & 13.42 & $15.06 \%$ & 16.91 & 13.25 & $9.88 \%$ & 18.23 & 25.43 & 21.74 \\
\hline Belgium & 3.36 & 2.96 & $1.67 \%$ & 3.03 & 4.24 & $4.86 \%$ & 3.02 & 6.57 & 1.40 \\
\hline Netherlands & 3.36 & 3.53 & $2.52 \%$ & 7.00 & 7.64 & $7.97 \%$ & 9.17 & 3.18 & 2.11 \\
\hline Switzerland & 15.38 & 18.04 & $22.15 \%$ & 16.00 & 19.19 & $15.91 \%$ & 15.49 & 9.14 & 13.48 \\
\hline Portugal & 2.65 & 2.04 & $1.38 \%$ & 1.64 & 1.77 & $2.00 \%$ & 1.80 & 1.74 & 1.16 \\
\hline Sweden & 16.20 & 13.35 & $11.67 \%$ & 8.83 & 10.12 & $11.68 \%$ & 9.41 & 5.07 & 9.77 \\
\hline Ireland & 9.12 & 10.35 & $7.86 \%$ & 5.62 & 6.00 & $10.12 \%$ & 7.32 & 2.23 & 8.73 \\
\hline Poland & 1.43 & 1.67 & $0.89 \%$ & 1.12 & 0.84 & $3.01 \%$ & 1.21 & 1.02 & 1.55 \\
\hline Romania & 0.86 & 0.99 & $1.13 \%$ & 0.93 & 0.88 & $2.67 \%$ & 0.91 & 1.43 & 0.95 \\
\hline Austria & 8.51 & 9.41 & $7.18 \%$ & 7.53 & 5.98 & $7.91 \%$ & 5.99 & 6.05 & 9.59 \\
\hline Denmark & 7.34 & 7.49 & $11.67 \%$ & 9.19 & 11.90 & $7.96 \%$ & 7.64 & 4.85 & 7.66 \\
\hline Serbia & 0.33 & 1.79 & $1.92 \%$ & 1.11 & 2.72 & $2.43 \%$ & 2.04 & 0.41 & 1.63 \\
\hline$R^{2}$ & 89.61 & 94.59 & $88.65 \%$ & 91.25 & 91.64 & $93.25 \%$ & 94.74 & 90.43 & 89.51 \\
\hline Tracking error & 0.13 & 0.69 & $1.18 \%$ & 1.51 & 1.06 & $0.38 \%$ & 0.81 & 0.88 & 1.08 \\
\hline
\end{tabular}

$R^{2}$ represents coefficient of determination and Tracking error captures the deviation between fund and benchmark (in italics)

resilient to the ongoing pandemic. In part, this performance could be attributed to the fact that these funds invest in businesses that provide innovative solutions to solve social issues and promote global well-being
The results on style analysis are presented in Tables 5, 6, and 7. During phase 1, we observe from Table 5 a skewness of debt, corporate money market, and infrastructure funds towards large-scale firms. While venture capital 
Table 7 Style analysis-phase 3

\begin{tabular}{|c|c|c|c|c|c|c|c|c|}
\hline Capital mar & & Money m & arket & Alterna & e investment & & & \\
\hline Equity (\%) & Debt $(\%)$ & Treasury & Corporate $(\%)$ & $\begin{array}{l}\text { Private } \\
\text { equity } \\
(\%)\end{array}$ & Real estate & $\begin{array}{l}\text { Venture } \\
\text { capital } \\
(\%)\end{array}$ & $\begin{array}{l}\text { Social entre- } \\
\text { preneurship } \\
(\%)\end{array}$ & Infrastructure (\%) \\
\hline
\end{tabular}

Size

Large

Mid

\subsection{3}

$$
77.62
$$

N/A $\quad 76.73$

21.06

N/A 20.65

Small

$R^{2}$

37.16

1.32

N/A

20.65
2.62

91.46

95.33

N/A $\quad 87.35$

Tracking error

0.61

1.34

N/A

0.88

Investment strategies

Growth

Value

Momentum

$R^{2}$

Tracking error

\subsection{8}

3.73

N/A

1.31

77.10

74.42

N/A

60.48

20.51

21.85

N/A

38.21

92.71

92.43

N/A

90.55

Sector

Manufacturing

0.49

1.17

N/A

1.24

Utilities

\subsection{2}

$13.39 \quad \mathrm{~N} / \mathrm{A} \quad 16.29$

Mining, construction

32.85

26.26

N/A $\quad 31.49$

and chemicals

Wholesale and retail

Agriculture, forestry $\quad 7.74$ and fishing

Services

$R^{2}$

8.29

9.90

N/A

5.69

43.61

N/A $\quad 33.71$

3.59

N/A

5.37

3.25

N/A $\quad 7.45$

3.72

92.48

N/A $\quad 92.49$

Tracking error

91.07

1.25

N/A

1.14

Country

Spain

Italy

2.04

$\begin{array}{lll}4.00 & 2.08 \% & 3.60\end{array}$

$2.05 \quad 2.53 \% \quad 2.80$

France

Germany

2.73

6.08

$7.46 \%$

10.69

10.87

$12.20 \% \quad 13.70$

$2.40 \quad 1.35 \% \quad 2.46$

Belgium

2.73

2.86

$2.04 \% \quad 5.67$

Switzerland

2.73

20.72

$25.01 \% \quad 20.06$

Portugal

17.36

1.65

$1.12 \% \quad 1.33$

Sweden

18.20

15.00

$13.11 \% \quad 10.93$

Ireland

9.59

10.88

$8.26 \% \quad 5.90$

Poland

Romania

Austria

Denmark

1.16

1.35

$0.72 \% \quad 0.91$

$0.80 \quad 0.92 \% \quad 0.76$

$10.02 \quad 7.64 \% \quad 8.01$

Serbia

$R^{2}$

$$
\begin{aligned}
& 0.70 \\
& 9.06
\end{aligned}
$$

9.38

$13.94 \% \quad 12.19$

$1.94 \quad 1.61 \% \quad 0.99$

$92.36 \quad 89.72 \% \quad 94.80$

96.04

$0.80 \quad 1.12 \% \quad 1.22$

$\begin{aligned} 9.35 & \text { N/A } \\ 51.19 & \text { N/A } \\ 39.46 & \text { N/A } \\ 90.54 & \text { N/A }\end{aligned}$

7.36

56.74

35.90

92.87

1.53

$1.06 \quad N / A$

\subsection{3}

22.81

40.56

89.74

\section{N/A}

N/A

27.54

63.56

N/A

N/A

8.90

$0.86 \quad N / A$

90.57

1.03

$\begin{array}{rrrrr}14.83 & \text { N/A } & 24.24 & 7.95 & 6.79 \\ 24.91 & \text { N/A } & 16.77 & 0.41 & 43.70 \\ 12.90 & \text { N/A } & 0.32 & 1.29 & 16.62\end{array}$

\subsection{5}

\section{N/A}

28.39

43.59

11.02

7.63

N/A

18.82

1.90

21.14

\subsection{8}

89.6

0.6

Tracking error

0.51

$\begin{array}{lll}0.80 & 1.12 \% & 1.22\end{array}$

$\begin{array}{rlrrr}2.72 & 3.23 \% & 2.53 & 3.50 & 1.74 \\ 2.05 & 1.99 \% & 1.86 & 7.06 & 2.12 \\ 7.77 & 5.80 \% & 10.01 & 24.99 & 12.54 \\ 10.73 & 8.01 \% & 14.77 & 27.50 & 17.61 \\ 3.44 & 3.94 \% & 2.44 & 6.98 & 1.13 \\ 6.19 & 6.46 \% & 7.43 & 3.37 & 1.71 \\ 23.66 & 19.96 \% & 19.48 & 9.88 & 17.21 \\ 1.43 & 1.62 \% & 1.46 & 1.71 & 0.94 \\ 11.37 & 13.13 \% & 11.57 & 2.98 & 11.98 \\ 7.31 & 10.63 \% & 8.69 & 2.19 & 9.18 \\ 0.68 & 2.44 \% & 0.98 & 1.00 & 1.25 \\ 0.71 & 2.17 \% & 0.74 & 1.40 & 0.77 \\ 7.37 & 8.42 \% & 7.38 & 2.94 & 10.21 \\ 13.20 & 10.82 \% & 9.47 & 3.28 & 10.04 \\ 1.36 & 1.39 \% & 1.18 & 1.23 & 1.57 \\ 93.25 & 89.15 \% & 91.42 & 93.54 & 90.54 \\ 0.95 & 1.31 \% & 0.94 & 1.02 & 1.48\end{array}$

$R^{2}$ represents coefficient of determination and Tracking error captures the deviation between fund and benchmark (in italics)

and social entrepreneurship funds dominate investment in small businesses. This is plausible for venture capital investment because they seek high returns by investing in early-stage size-constrained firms. Similarly, social entrepreneurship landscape is concentrated towards small firms.

In terms of investment strategies, we see a preference of equity fund managers towards growth while for fixed income 
it is value investing. This is logical as value firms mostly have credit stability and are attractive for debt funds. On the contrary, growth firms provide opportunity for investment appreciation and are preferred by equity funds. For the sector styles, we observe concentration of social entrepreneurship towards services while capital, money market, private equity, and venture capital funds were investing mostly in manufacturing. In the country specification, Germany and France appeared to be favored locations by the funds. The social entrepreneurship funds had approx. $45 \%$ investment, treasury around $47 \%, 36 \%$ for private equity, and $35 \%$ for equity funds in these two countries. It is interesting to note that France and Germany, respectively, are ranked 3rd and 4th in number of cases as on May 24th.

The drift in style is clearly observable from Tables 6 and 7. The equity funds increased their exposure to large firms (50.2\%) during phase 2 and (56.7\%) phase 3. This is significantly high compared to $33 \%$ investments in large firms during phase 1 . The corporate money market funds increased their investments to $67.9 \%$ and $76.7 \%$, respectively, in large firms in contrast to $52.1 \%$ during phase 1 . However, in terms of size, we do not see a significant drift across the three phases for social entrepreneurship funds. For conventional capital and money market funds, this is extremely logical in a turbulent period to move the investments towards safer options. In case of social entrepreneurship funds, we suspect that funds manager realize the resilience towards Covid-19 and hence did not feel the need to change the investment mix. It is worth noting that investment style for this category did not change much across sectors as well as country specification during the three phases.

For equity funds, there is a significant transition from growth to value stocks. During phase 2, the investment in value firms increased to $68.1 \%$ and ultimately to $77.1 \%$ in phase 3 . In the money market funds, we see a marginal switch of 53\% and $63.4 \%$ to value firms. The change in investment styles continues across sectors. The capital, money, and most of the alternative investments moved their funds to utilities, wholesale, and retail firms as the Covid19 situation evolved. The equity funds have $63 \%$ and $67 \%$ investment in these sectors during phases 2 and 3 . The fixed income funds investment was $64.1 \%$ during phase 2 that was increased to $70 \%$ in phase 3 . Owing to the fact that products of wholesale, retail, and utilities include necessities and possibly have lower sensitives to Covid-19 turmoil. This possible explains the transition of funds during the later periods of the pandemic.

There are some interesting insights from country-specific styles. As noted earlier, Germany and France are largely affected by the spread of coronavirus and our results demonstrate the impact. The cumulative investment of equity funds in these two countries declined to $25.1 \%$ during phase 2 and
$20.6 \%$ in phase 3 . Similar trend is observable in treasury that declined to a cumulative of $24.9 \%$ in phase 2 and $10.1 \%$ in phase 3 . On the contrary, we observe a significant increase in investment flow towards Switzerland, Sweden, Ireland, Austria, and Denmark. This increase is consistent across all funds categories with the exception of social entrepreneurship. Interestingly, these are the countries that are ranked low in number of cases among the EU member states. Therefore, it seems that funds managers were moving their investments from significantly infected locations to the ones that are having lower impact.

\section{Conclusion}

The last few months have been exceptional in terms of socioeconomic circumstances of Covid-19. The massive spread of the novel coronavirus has seriously impacted the financial system resulting in a landslide challenges to market participants and policymakers. This study is a preliminary attempt to evaluate the effect of Covid-19 on various categories of mutual funds in European Union. We attempt to investigate how the dynamic evolution of this pandemic impacted the risk-adjusted returns and resulted in possible drift of investment styles. For this purpose, we divide the last five months into three phases that related to an initial period when the infection was limited to China, a phase 2 when this became a global issue and phase 3 which is mostly marked by stringent lockdowns.

We used risk-adjusted performance measures to comparatively assess the funds across various subcategories. The social entrepreneurship funds demonstrated superior performance compared to other types and this remained consistent even when the spread worsened in phases 2 and 3 . The style analysis provided some interesting insights. We observe a transition from riskier to relatively safer options in terms of size and investment strategies. Similarly, there was a clear switch in investments towards non-cyclical sectors. Lastly, the investment moved from countries with higher infections to those with relatively lower number of cases. The only subcategory where we observed consistency in investment styles across all phases was social entrepreneurship funds. This emanates from their superior risk-adjusted performance and therefore fund managers do not need to change the investment mix.

The pandemics are very uncommon and therefore our study provides a unique evidence on how Covid19 has impacted mutual funds till now. However, these are some early findings based on a limited dataset and hence should be considered with caution. We suggest that as the situation is dynamic and evolving, the impact should be continuously monitored for a more thorough understanding. 
Acknowledgements We would like to thank anonymous referees and editor Dr. Marielle de Jong for their constructive comments on this evolving topic.

\section{References}

Almond, D. 2006. Is the 1918 influenza pandemic over? Long-term effects of in utero influenza exposure in the post-1940 U.S. population. Journal of Political Economy 114 (4): 672-712. https:// doi.org/10.1086/507154.

Assaf, A. 2015. Value-at-risk analysis in the MENA equity markets: Fat tails and conditional asymmetries in return distributions. Journal of Multinational Financial Management 29: 30-45. https://doi. org/10.1016/j.mulfin.2014.11.002.

Baele, L., G. Bekaert, K. Inghelbrecht, and M. Wei. 2019. Flights to safety. The Review of Financial Studies 33 (2): 689-746. https:// doi.org/10.1093/rfs/hhz055.

Bloom, D.E., D. Cadarette, and J. Sevilla. 2018. The economic risks and impacts of epidemics. Washington: IMF F\&D Magazine.

Blundell-Wignall, A. 2011. Solving the financial and sovereign debt crisis in Europe. OECD Journal 2: 201-224.

Cao, C., P. Iliev, and R. Velthuis. 2017. Style drift: Evidence from small-cap mutual funds. Journal of Banking and Finance 78: 42-57. https://doi.org/10.1016/j.jbankfin.2017.01.009.

Carhart, M.M. 1997. On persistence in mutual fund performance. Journal of Finance. https://doi.org/10.1111/j.1540-6261.1997. tb03808.x.

Chevalier, C., and S. Darolles. 2019. Trends everywhere? The case of hedge fund styles. Journal of Asset Management 20 (6): 442-468. https://doi.org/10.1057/s41260-019-00141-5.

Chevalier, J., and G. Ellison. 2017. American Finance Association are some mutual fund managers better than others cross-sectional patterns in behavior and performance author(s): Judith Chevalier and Glenn Ellison Source. The Journal of Finance 54 (3): 875-899.

Deng, G., T. Dulaney, C. McCann, and O. Wang. 2013. Robust portfolio optimization with Value-at-Risk-adjusted Sharpe ratios. Journal of Asset Management 14 (5): 293-305. https://doi. org/10.1057/jam.2013.21

Fama, E.F., and K.R. French. 2010. Luck versus Skill in the CrossSection of Mutual Fund Returns. The Journal of Finance 65 (5): 1915-1947.

Fogli, A., and L. Veldkamp. 2013. Germs. Social Networks, and Growth. https://doi.org/10.21034/sr.572.

Golec, J.H. 1996. The effects of Mutual Fund Managers' Characteristics on Their Portfolio Performance, risk and fees. Financial Services Review 5 (2): 133-147. https://doi.org/10.1016/S1057 -0810(96)90006-2.

Herrmann, U., M. Rohleder, and H. Scholz. 2016. Does style-shifting activity predict performance? Evidence from equity mutual funds. Quarterly Review of Economics and Finance 59: 112-130. https ://doi.org/10.1016/j.qref.2015.03.003.

Hou, A.J., I. Khrashchevskyi, and J. Peltomäki. 2019. Hedge and safe haven investing with investment styles. Journal of Asset Management 20 (5): 351-364. https://doi.org/10.1057/s41260-019-00127 -3 .

Iglesias, E.M. 2015. Value at Risk and expected shortfall of firms in the main European Union stock market indexes: A detailed analysis by economic sectors and geographical situation. Economic Modelling 50: 1-8. https://doi.org/10.1016/j.econmod.2015.06.004.

Kaiser, L. 2020. ESG integration: Value, growth and momentum. Journal of Asset Management 21 (1): 32-51. https://doi.org/10.1057/ s41260-019-00148-y.
Kelly, E. 2011. The scourge of Asian Flu: In utero exposure to pandemic influenza and the development of a cohort of British children. Journal of Human Resources 46 (4): 669-694.

Lannoo, K., E. Pyykkö, and M. Barslund. 2013. Household debt and the European crisis Ales Chmelar.

Naqvi, B., S.K.A. Rizvi, N. Mirza, and K. Reddy. 2018. Religion based investing and illusion of Islamic Alpha and Beta. Pacific Basin Finance Journal. https://doi.org/10.1016/j.pacfin.2018.02.003.

Parikh, H. 2019. Emerging market equity benchmarks for Japanese investors: Countries, sectors or styles? Journal of Asset Management 20 (4): 289-300. https://doi.org/10.1057/s41260-019-00123 $-7$.

Pedersen, C.S., and T. Rudholm-Alfvin. 2003. Selecting a risk-adjusted shareholder performance measure. Journal of Asset Management 4 (3): 152-172. https://doi.org/10.1057/palgrave.jam.2240101.

Pezier, J., and A. White. 2006. The relative merits of investable hedge fund indices and of funds of hedge funds in optimal passive portfolios. ICMA Centre Discussion Papers in Finance, pp. 1-32.

Reddy, K., N. Mirza, B. Naqvi, and M. Fu. 2017a. Comparative risk adjusted performance of Islamic, socially responsible and conventional funds: Evidence from United Kingdom. Economic Modelling. https://doi.org/10.1016/j.econmod.2017.07.007.

Scholz, H. 2007. Refinements to the Sharpe ratio: Comparing alternatives for bear markets. Journal of Asset Management 7 (5): 347-357. https://doi.org/10.1057/palgrave.jam.2250040.

Sha, Y. 2020. The devil in the style: Mutual fund style drift, performance and common risk factors. Economic Modelling 86: 264 273. https://doi.org/10.1016/j.econmod.2019.10.004.

Sharpe, W. 1992. Asset allocation: Management style and performance measurement. The Journal of Portfolio Management 18 (2): 7-19. https://doi.org/10.3905/jpm.1992.409394.

$\mathrm{Su}$, J.Bin. 2015. Value-at-risk estimates of the stock indices in developed and emerging markets including the spillover effects of currency market. Economic Modelling 46: 204-224. https://doi. org/10.1016/j.econmod.2014.12.022.

Weng, H., and S. Trück. 2011. Style analysis and Value-at-Risk of Asia-focused hedge funds. Pacific Basin Finance Journal 19 (5): 491-510. https://doi.org/10.1016/j.pacfin.2011.05.002.

Yamey, G., M. Schäferhoff, O. Aars, B. Bloom, D. Carroll, M. Chawla, V. Dzau, R. Echalar, I.S. Gill, T. Godal, S. Gupta, D. Jamison, P. Kelley, F. Kristensen, C. Mundaca-Shah, B. Oppenheim, J. Pavlin, R. Salvado, P. Sands, E. Whiting, et al. 2017. Financing of international collective action for epidemic and pandemic preparedness. The Lancet Global Health 5 (8): e742-e744. https://doi. org/10.1016/S2214-109X(17)30203-6.

Zabai, A. 2017. Household debt: Recent Developments and challenges 1. BIS Quarterly Review.

Publisher's Note Springer Nature remains neutral with regard to jurisdictional claims in published maps and institutional affiliations.

Syed Kumail Abbas Rizvi, CFA, FRM Kumail Rizvi is a Chartered Financial Analyst (CFA) and Certified Financial Risk Manager (FRM) by profession and simultaneously occupied with Academic and Corporate Institutions in the domain of Investment Analysis and Risk Management. He is currently working as Professor of Finance at Lahore School of Economics. He has published several research articles in top quality journals including 'Pacific-Basin Finance Journal', 'Quantitative Finance', 'Resources Policy', 'Applied Financial Economics', 'Managerial Finance', and 'Research in International Business and Finance'.

Nawazish Mirza obtained a Phd in finance from University of Paris Dauphine (now Dauphine-PSL) in 2010. Currently, he is an Associate Professor of Finance at La Rochelle Business School-Excelia Group, 
France. His research interests include investment management, credit ratings, risk management, financial intermediation and valuations. $\mathrm{He}$ has extensive professional and consulting experience in credit ratings, investment banking and valuation of new technologies. His academic contributions have appeared in Pacific Basin Finance Journal, Economic Modelling, Resources Policy, Research in International Business and Finance, Journal of Quantitative Economics, among others.

Bushra Naqvi is an Associate Professor and Associate Dean Academics at Suleman Dawood School of Business, Lahore University of Management Sciences. She holds doctorate in financial economics from Pantheon Sorbonne (University of Paris 1). Her research interests lie in the field of financial economics, financial markets, financial intermediation, monetary economics, corporate finance, governance and financial risk management. She has published several research articles in top quality journals including 'Pacific-Basin Finance Journal', 'Quantitative Finance', 'Applied Financial Economics', and 'Economic Modelling'. Besides her research and academic concentrations, Dr. Naqvi also holds the charter of Financial Risk Manager (FRM) from Global Association of Risk Professionals (GARP), USA.

Birjees Rahat is an Adjunct Faculty of Finance at La Rochelle Business School—Excelia Group, France. Her research interests include risk management, credit ratings, socially responsible investments, sustainability and environmental finance. She has professional experience in credit ratings and portfolio risk management. Her academic contributions have appeared in Economic Modelling, Economics Bulletin and Economic Research. 